\title{
破損リスク軽減を目的とした 新規ガラスアンプル外筒被覆包装の有用性
}

下枝貞彦 ${ }^{* 1 a)}$, 中澤一純 ${ }^{1}, 大$ 和 進 $^{2}$, 笹木睦子 $^{3}$ ，

河野健治 ${ }^{3}$, 太田 伸 $^{4}$

長野赤十字病院薬斉部 ${ }^{1}$, 新潟薬科大学薬学部薬品分析化学教室 ${ }^{2}$

新潟薬科大学薬学部臨床薬斉学教室 ${ }^{3}$

東京薬科大学薬学部臨床薬剂学研究室 $\left.\right|^{4}$

\section{Usefulness of Novel Glass Ampule Cover in Reducing Breakage Risk}

\author{
Sadahiko Shimoeda*1a), Kazuyoshi Nakazawa ${ }^{1}$, Susumu Yamato ${ }^{2}$, Mutsuko Sasaki ${ }^{3}$, \\ Kenji Kawano ${ }^{3}$ and Shin Ohta ${ }^{4}$ \\ Nagano Red Cross Hospital Department of Pharmacy ${ }^{1}$ \\ Niigata University of Pharmacy and Applied Life Sciences Faculty of Pharmaceutical Sciences \\ Department of Pharmaceutical and Analytical Chemistry ${ }^{2}$ \\ Niigata University of Pharmacy and Applied Life Sciences \\ Faculty of Pharmaceutical Sciences Department of Clinical Pharmaceutics ${ }^{3}$ \\ Tokyo University of Pharmacy and Life Science Faculty of Pharmaceutical Sciences \\ Department of Clinical Pharmaceutics ${ }^{4}$ \\ $\left[\begin{array}{l}\text { Received January 21, } 2008 \\ \text { Accepted March 26, } 2008\end{array}\right]$
}

We investigated the influence of the ampule package in reducing the risk of " one-point cut" glass injection ampules breaking when dropped. Four test products were subjected to horizontal and vertical drop tests from heights of 60 and 85 $\mathrm{cm}$ according to JIS Z 0202 in the Japanese Industrial Standards. A novel square ampule cover that was sufficiently larger than the glass ampule and sealed with a polypropylene film markedly reduced the breakage risk (Tukey's HSD test: P < 0.001 ), and there was no significant correlation between the height from which ampules were dropped and breakage (analysis of variance $: P=0.069$ ).

We concluded that the novel ampule cover was useful for the packaging of injectable drugs used in clinical practice as it not only reduces the risk of glass ampules breaking but also prevents scattering of the solutions contained in them.

Key words — drug packages, glass ampule, breakage risk, drop test, impact-absorbing ability

緒言

医薬品の名称や包装形態が原因となり，誤投薬や誤調 剂の行われる例が散見される ${ }^{1-6)}$. 現在, 多くの製薬企 業では, 医薬品の名称や包装形態が，医療機関における 投薬時のエラーやリスクを軽減するうえで大変重要な役
割を果たしていることを認識し，製斉設計を行うことが 一般的となりつつある.さらに，投薬に伴うコンプライ アンスの向上を目的に，患者が使用しやすい製闵設計と はいかにあるべきなのかを検証した報告が，製剤設計の 変更に活用されている7-11).

特に, 最近の傾向として, 当該製剂がどのような環境 下で保管, 調剂された後, 投薬されるのか, 兴の一連の

* 長野市若里 5-22-1; 5-22-1, W akasato, Nagano-shi, Nagano, 380-8582 Japan

a現) : 新潟薬科大学薬学部 臨床薬学研究室(新潟市秋葉区東島 265-1; 265-1, Higashijima, A kiha ku, Niigata shi, Niigata, 950-8603 Japan) 
プロセスを医療機関に赴き見学することを希望する製薬 企業も現れている.このような動きは，製阂設計に携わ る専門技術者が，医療現場を知らずして，投薬時のエ ラーやリスクを軽減するための製剤は製造できないとの 認識を持つようになったことに起因すると考えられる．

製薬企業による情報收集方法の変化により，医療現場 では，投薬時エラーやリスクの軽減に一定の効果をもた らすことが期待される医薬品包装がすでに実用化されて いる ${ }^{12-15)}$ ，㚇の一例が，ワンポイントカット部を有する ガラスアンプル(以下 , ガラスアンプルと略す)に封入さ れた麻薬注射剂の転がり防止ガラスアンプルラベルであ る. 本ラベルは, ラベルに 3 点の突起部分を設けること でガラスアンプルの転がりを防ぐ方式と，ラベルをガラ スアンプルに完全密着させず，はみ出し部分を設けるこ とでガラスアンプルの転がりを防ぐ方式の二つに大別さ れる、厳格な管理体制が必要な麻薬注射剂は, 現在, ガ ラスアンプルに封入された製品が大半を占め，常に破損 のリスクを伴っている．兰こで，このような転がり防止 ラベルを使用することで， ガラスアンプルの破損リスク を軽減しようとする試みが行われ，一定の効果が得られ ているものと考えられる . しかし, 転がり防止ラベルの 効果には限界があり，転がりを防止しても，医療従事者 が手元を誤り，ガラスアンプルが落下すれば，衝撃に伴 う破損が生じることから，依然としてガラスアンプルに 封入された麻薬注射剂の取り扱いには細心の注意が求め られている。

乥こで, 落下衝撃に対する強度を増し, 破損リスクを 軽減する目的で, ガラスアンプル注射剂の包装形態を検 討した . 光の結果, ガラスアンプル注射剂の破損リスク を軽減することを可能とする，新規ガラスアンプル外筒 被覆包装に関する新知見を得たので，以下に報告する .
方法

1. 供試品

すべての供試品は内容量 $2 \mathrm{~mL}$ の注射用蒸留水が封入 されたガラスアンプルを用い，以下に定める供試品 $\mathrm{A}$ ， 供試品 $\mathrm{B}$, 供試品 $\mathrm{C}$, 供試品 $\mathrm{D}$ の包装形態について, 落下衝撃に対するガラスアンプル破損防止効果の評価を 行った(図 1).

\section{1)供試品 $A$}

ガラスアンプルのみの対照品 .

2)供試品 B

ガラスアンプルの両端をポリプロピレン製フィルムで 円筒状に被覆したもの．本外筒は円筒状のため，ガラス アンプル両端部は開放状態となっており，アンプル破損 が生じると内容液が飛散する構造となっている．

3)供試品 C

ガラスアンプル全体をポリエチレン製フィルムで被覆 し，中央部にミシン目を入れ開封作業を容易にしたも の. 本品はすでに , メチコバール ${ }^{\circledR}$ 注射液 $509 \mathrm{~g}$ ）ケイ ツー ${ }^{\circledR} \mathrm{N}$ 静注用 $10 \mathrm{mg}$ (ともにエーザイ(株))に採用されて いる包装形態であるが , 現行包装より耐水性の高いポリ エチレン製フィルムを使用し，内部でアンプル破損が生 じても内容液が飛散することなく回収が可能な性状に改 良を加えたものである。

4)供試品 D

ガラスアンプル全体を，十分な余白部分を設け，ガラ スアンプルより大きな正方形のポリプロピレン製フィル ムを用い密封し，フィルム上部にノッチを入れ開封作業 を容易にしたもの．供試品Ｃと同樣に耐水性が高く， 内部でアンプル破損が生じても内容液が飛散することな く回収が可能である .
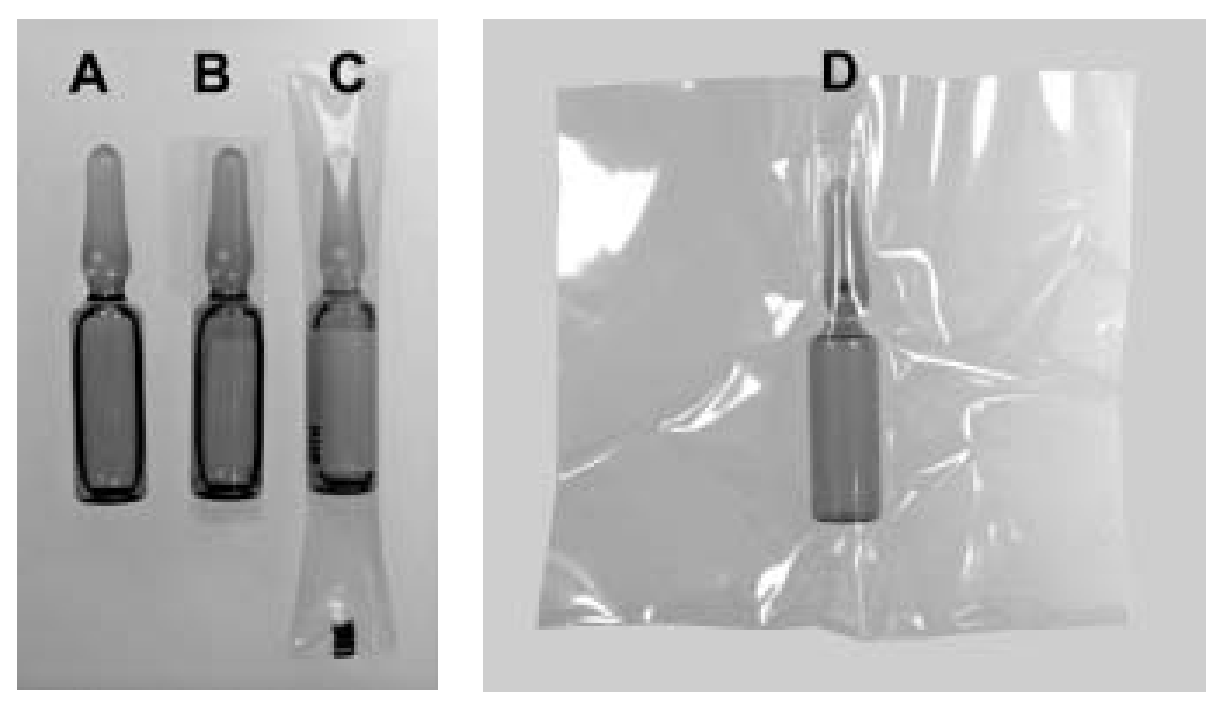

図 1 . 供試品 $\mathrm{A}$, 供試品 B, 供試品 C, 供試品 D の外観 
なお，供試品 B，C，Dの材質は以下のような経緯で 決定した。(1)供試品 B：ポリエチレンテレフタレート, ポリエチレン , ポリプロピレンの三種類を検討した . 1 $\mathrm{mL}$ ガラスアンプルを用いた試作の段階において，ポリ エチレンテレフタレートはフィルムに貼付後，経時的に ラベルの浮き剥がれが確認された . また ，ラベル貼り機 でアンプルにフィルムを貼付する際に , ポリエチレンで はフィルムが柔らかく貼り付けできない場合があること を確認した . 弚こで, ポリプロピレンを使用した . (2)供 試品 C : 開発当初は, 両端を粘着剂で圧着する方法を検 討した．しかし，圧着直後は問題がないものの，経時的 に包装が開封することが確認された .この問題点を解決 する方法(粘着剂の変更など)を検討したが, 最終的には 熱で溶着させる方法が最も強度が大きいことを確認し た．乥こで，熱による溶着に適しており，加工しやすい 材質特性を満たすポリエチレンを使用した . (3)供試品 $\mathrm{D}$ : この形状ではポリエチレンテレフタレート，ポリエ チレン , ポリプロピレンの三種類間で大差はなく，フィ ルム材質に制限がなかったことから，コストが安いポリ プロピレンを使用した . また，供試品の材質自体には， 落下衝撃に対する直接的な緩衝能力は備わっておらず，

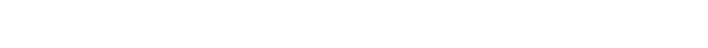

さらに, ガラスアンプルは,いずれも第15改正日本 薬局方の注射㓢用ガラス容器試験法に適合する, ホウケ イ酸ガラスアンプルを用いた . 1回の落下試験に使用す る供試品は, 各群ともに15本とし, 落下試験はいずれ も室温下で実施した .

\section{2. 試験方法}

ガラスアンプル破損を防ぐ新規包装形態の有用性を客 観的に評価できるよう，日本工業規格(JIS：Japanese Industrial Standards)で定められている，JIS Z0202(包装貨 物 一落下試験方法)に準拠し試験を行った。本試験方法 は, 自由落下試験装置を用いた落下試験(方法 A)と衝撃 試験装置を用いた落下試験(方法B)から構成されてい る.このように落下試験が, 方法 A と方法 B の二種類 より構成されているのは, 本試験が, 包装貨物の流通過 程において受ける振動, 落下衝撃および圧縮に対する, 包装の保護が適正であるかどうかを評価するための試験 方法について規定された JIS Z0200(包装貨物－評価試験 方法通則)の一部であることに起因している．しかし， 一般に，医療現場で医薬品が使用される際，振動や圧縮 がガラスアンプルに加わる可能性は少ないと考えられ る. 弚こで, 本試験では, 落下衝撃に対する評価のみを 行うことし, 自由落下試験装置を用いる落下試験(方法 A)による新規包装形態の有用性評価を行った .

\section{3. 試験装置}

JIS Z0202で定める自由落下試験装置の条件を満たす ランスモント社製包装貨物落下試験機ドロップテス ター ${ }^{\circledR}$ (Model PDT-56E)を用いた(図 2)．また，ガラスア ンプルの落下面は, JIS Z0200で規定されている鋼板を 用いた。

\section{4. 落下高さ}

JIS Z0200，JIS Z0202において，本供試品の重量条件 で落下試験を行う場合，落下高さは光れ光れ流通条件に よって , レベル |の $80 \mathrm{~cm}$, レベル $11 の 60 \mathrm{~cm}$, レベル $I I I の 40 \mathrm{~cm}$ ，レベルIVの $30 \mathrm{~cm}$ と，4段階に区分されて いる．一般に，医薬品包装の落下試験高さは，レベルII で十分とされている．しかし，麻薬や抗がん斉などが充 填されたガラスアンプルでは，落下衝撃に対してより高 い破損防止効果が求められることから，落下高さ設定を 一段階上げ，レベル $11 の 60 \mathrm{~cm}$ で試験を行うこととし た . 一方 , 現在多くの施設で普及している調製台の高さ は $85 \mathrm{~cm}$, パーソナルコンピューター対応型事務机の高 さは $70 \mathrm{~cm}$ である．弚こで，臨床現場で使用される状況 を想定し，高さ $85 \mathrm{~cm}$ でも同樣の試験を実施することと した。

\section{5. 落下方法}

供試品の形態から，水平落下試験を原則とし，自由落 下試験装置に垂直装填が可能な供試品 $A$ と供試品 $B$ に ついては, 垂直落下試験も行った(図 3) . 水平落下試験 を行う際は, ガラスアンプルのワンポイントカットマー

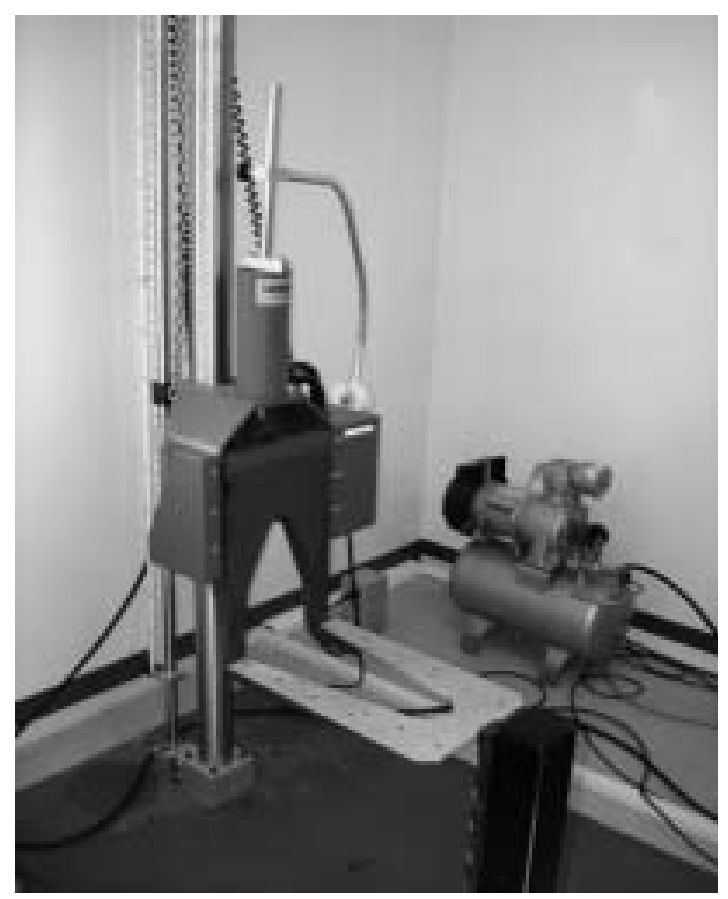

図 2. 包装貨物落下試験機の外観 


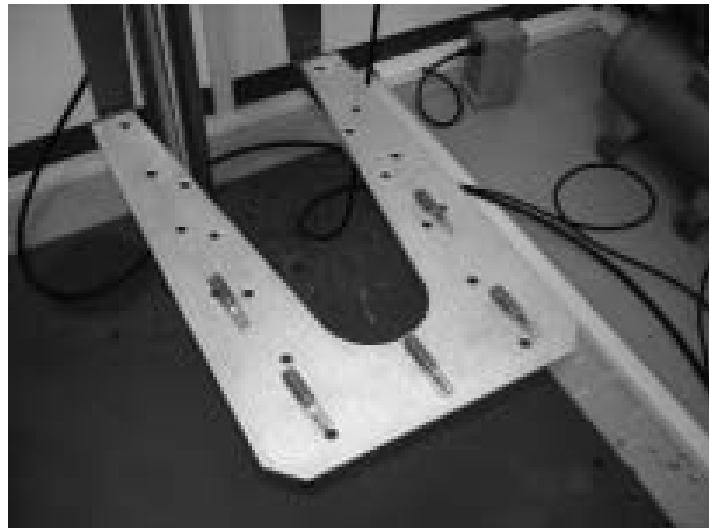

水平落下試験時

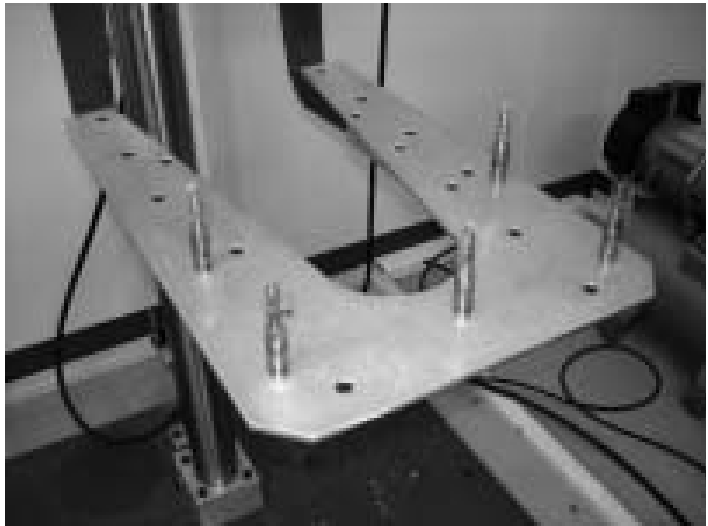

垂直落下試験時

図 3. 包装貨物落下試験後への供試品装填方法

ク部が天面を向くよう装填した . なお，自由落下試験装 置は, 被験物を装填したアーム部分が圧縮空気の力で瞬 時に下方移動し，ほぼ落下前の状態を保持しながら落下 面に被験物が落下する仕樣となっている．したがって， ガラスアンプルは, 水平落下試験では水平状態のまま, 垂直落下試験では垂直状態のまま，落下面に到達し，衝 撃を受ける．

\section{結＼cjkstart果}

\section{1. 水平落下試験}

表 1 に, 水平落下試験における各包装形態のガラスア ンプル破損状況を示した . 落下高さ $60 \mathrm{~cm}$ で実施した水 平落下試験の結果, ガラスアンプル破損の有/無は, 供 試品 A が 13/2, 供試品 B が 14/1, 供試品 C が 12/3, 供試品 D が $1 / 14$ であり，供試品 D で有意差が認められ た(Tukey's HSD 検定 : P<0.001).

また，落下高さ $85 \mathrm{~cm}$ で実施した水平落下試験の結 果 , ガラスアンプル破損の有/無は, 供試品 A が 15/0, 供試品 B が $14 / 1$, 供試品 C が 11/4, 供試品 D が $7 / 8$ であり，供試品 D で有意差が認められた(Tukey's HSD
検定 : P<0.001).なお，落下高さとガラスアンプル破 損との間に有意差は認められなかった(分散分析 : $\mathrm{P}=$ 0.069)

\section{2. 垂直落下試験}

表 2 に, 垂直落下試験における各包装形態のガラスア ンプル破損状況を示した . 落下高さ $60 \mathrm{~cm}$ で実施した垂 直落下試験の結果, ガラスアンプル破損の有/無は，供 試品 A が11/4，供試品 B が1/14であり，供試品 Bで 有意差が認められた(Tukey's HSD 検定 : P<0.001).

また，落下高さ $85 \mathrm{~cm}$ で実施した垂直落下試験の結 果 , ガラスアンプル破損の有/無は, 供試品 A が 14/1, 供試品 B が $2 / 13$ であり，供試品 B で有意差が認められ た(Tukey's HSD 検定 : P<0.001).なお，落下高さとガ ラスアンプル破損との間に有意差は認められなかった (分散分析 : $P=0.136$ ).

\section{3. ガラスアンプル破損後の耐水性}

今回の落下試験において，供試品 C, 供試品 D では， ガラスアンプルが外筒被覆包装内で破損した場合でも， 兴の直後から内容液が外部に漏れ出す事例は確認されな
表 1. 水平落下に対するガラスアンプル破損の有無

\begin{tabular}{|c|c|c|c|}
\hline \multirow{2}{*}{ 落下高さ(cm) } & \multirow{2}{*}{ 供試品 } & \multicolumn{2}{|c|}{ 破損の有無(本) } \\
\hline & & 有 & 無 \\
\hline \multirow{4}{*}{60} & $\mathrm{~A}$ & 13 & 2 \\
\hline & $B$ & 14 & 1 \\
\hline & $\mathrm{C}$ & 12 & 3 \\
\hline & D & 1 & 14 * \\
\hline \multirow{4}{*}{85} & A & 15 & 0 \\
\hline & $B$ & 14 & 1 \\
\hline & C & 11 & 4 \\
\hline & D & 7 & $8 *$ \\
\hline
\end{tabular}

表 2 . 垂直落下に対するガラスアンプル破損の有無

\begin{tabular}{|c|c|c|c|}
\hline \multirow{2}{*}{ 落下高さ (cm) } & \multirow{2}{*}{ 供試品 } & \multicolumn{2}{|c|}{ 破損の有無(本) } \\
\hline & & 有 & $\begin{array}{l}\text { 無 } \\
\end{array}$ \\
\hline \multirow{4}{*}{60} & A & 11 & 4 \\
\hline & B & 1 & $14 *$ \\
\hline & $\mathrm{C}$ & - & - \\
\hline & $\mathrm{D}$ & - & - \\
\hline \multirow{4}{*}{85} & $A$ & 14 & 1 \\
\hline & B & 2 & $13 *$ \\
\hline & $\mathrm{C}$ & - & - \\
\hline & $D$ & - & - \\
\hline
\end{tabular}


かった 、さらに, 自由落下試験装置を用いず，落下高さ $85 \mathrm{~cm}$ で自然落下させ破損した供試品 C, 供試品 D 光れ

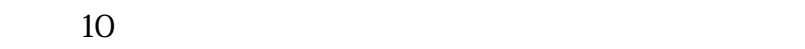
察したところ，1時間が経過しても内容液の滲出はなく 24 時間後の時点でも外部への滲出は確認できなかった .

\section{考察}

供試品 $\mathrm{A}$ ，供試品 $\mathrm{B}$ ，供試品 $\mathrm{C}$ ，供試品 $\mathrm{D}$ の落下衝撃 に対するガラスアンプル破損防止効果に対する評価を 行った結果から，水平落下では供試品 D が，最も衝撃 吸収能力が高く, ガラスアンプル破損の起こりにくい包 装形態であることが明らかとなった . また，垂直落下と いう条件下であれば，ガラスアンプル底部の衝撃吸収能 カが高い供試品 $\mathrm{B}$ も，破損の起こりにくい包装形態で あることが明らかとなった，今回の試験系では，供試品 $C$ と供試品 $D$ に対し，垂直落下試験を行うことは不可 能であったが , 供試品 B に対して行った垂直落下試験 の結果から，供試品 $\mathrm{C}$ と供試品 $\mathrm{D}$ も垂直落下に対して 優れた衙撃吸収能力を有していると推測される．しか し，臨床現場において，ガラスアンプルはさまざまな角 度で落下することから, 落下方向により衝撃吸収能力に 差異のある包装形態は問題がある．したがって，今回落 下試験を行った供試品 $\mathrm{A}$, 供試品 $\mathrm{B}$, 供試品 $\mathrm{C}$, 供試品 Dのうち, 最も落下衝撃に対する強度が高く，ガラスア ンプル破損リスク軽減効果の期待できる新規ガラスアン プル外筒被覆包装は，供試品 D であると結論された .

しかし, 供試品 D は, JIS Z0200, JIS Z0202の落下 試験において，レベル川の落下高さに適合する包装形態 であるが，医療現場を再現した落下高さ $85 \mathrm{~cm}$ では，破 損防止率が $50 \%$ 以下であり，改良の余地を残す結果と なった 。

医療技術の進歩や，疼痛緩和に対する考え方の变化に より，日本国内における医療用麻薬の施用量は，年々増 加している .さらに, 患者の病態に応じた疼痛緩和の必 要性か認識され，医療用麻薬の種類，斉型ならびに規格 か増え，产の取り扱いか煩雑となっている.したがって， 医療機関における麻薬施用の機会が増えることで, ガラ スアンプルに封入された麻薬注射剂の取り扱いを誤りガ ラスアンプルを破損させるリスクも高くなっている .

今回の落下試験において, 供試品 $\mathrm{D}$ は, 誤ってガラ スアンプルを落下させたときのガラスアンプル破損リス クを軽減するとともに，ガラスアンプルが外筒被覆包装 内で破損し 24 時間が経過しても，内容液が外部に漏れ 出す事例は確認されなかった。したがって, 供試品 D をガラスアンプルに封入された麻薬注射㓢の外筒被覆包 装として使用すれば，ガラスアンプル破損事故が生じて も，内容液の回収が容易で, 事故現場の確認作業や後処
理を迅速正確に行うことが可能となる．

さらに, 近年抗がん斉による外来化学療法が一般化 し，煩雑な環境下で注射斉調剂を行わなければならない 現状や, 診断群分類(Diagnosis Procedure Combination: DPC)による診療報酬の定額評価制度導入に伴う薬剂費 用削減の必要性を考慮すると，抗がん斉の外筒被覆包装 に本形態を導入することも効果的であると考えられる． 特に，ガラスアンプル破損に伴う外部環境への抗がん斉 飛散は，医療従事者ばかりでなく，患者や単の家族を含 む第三者へ，抗がん斉暴露を生じる可能性も否定できな い. 抗がん斉暴露対策が，抗がん斉の調製を行う者には 防護服，防護眼鏡，マスク，ゴム手袋などを着用し，安 全キャビネットを使用することで万全を期しているのに 対し, 注射薬計数調剂や爫の後の運搬に係る者は，ほぼ 無防備の状態である．したがって，本包装形態はあらゆ る場面において，ガラスアンプル破損に伴う抗がん剂暴 露のリスクを軽減する効果が期待される．しかし，一般 に，ガラスアンプル破損に伴う抗がん剂暴露のリスク は, 抗がん斉の注射薬計数調剂や少の後の運搬時より， 計量調剂時に多い．本包装形態は，落下に伴うガラスア ンプル破損防止効果は確認されているが，計量調剂時に 生じる抗がん斉暴露に対する直接的なリスク軽減効果は 確認されていない、したがって，計量調斉時に生じる抗 がん㓢暴露に対しては，抗がん斉の調製を行う者が防護 服，防護眼鏡，マスク，ゴム手袋などを着用し，安全 キャビネットを使用する従来どおりの方法が，リスク軽 減対策として最善であることに変わりはない，また，本 包装形態は，フィルム開封時や光の後のアンプル取り出 し工程時に，新たな破損リスクが発生する可能性も否定 できない．しかし，供試品 D で使用したポリプロピレ ン製フィルムは，ノッチを入れることにより，余分な力 を加えず開封できる性質を有することから，従来どおり のガラスアンプル取り扱い方法で対応可能であり，新た な破損リスクが生じる可能性は回避できるものと考えら れる。

一方，すでに多くの医薬品で採用されている，プレ フィルドシリンジ製剤やポリアンプル製剤は，落下に伴 う破損防止対策として有用性が高く，注射調剤に伴うミ スも防止できることから注目されている ${ }^{13-15)}$. しかし， プレフィルドシリンジ製剤はガラスアンプル製剤に比 ベ，より多くの保管スペースを必要としたり，廃棄物量 の増大が問題となる . また, ガラスアンプル製剂に比 ベ, プレフィルドシリンジ製剂，ポリアンプル製剂で は, 容器への薬斉吸着ならびに収着, 容器気密性の低 下，内容物の易改ざん性が共通の問題点となる．

したがって，ガラスアンプル製阂の特性を生かすとと もに，ガラスアンプル破損リスクを軽減し，ガラスアン プル内容液か榌散することを防止する新規ガラスアンプ 
ル外筒被覆包装は, 臨床現場で有用性が高い医薬品包装 である . 同時に，供試品 $\mathrm{D}$ は，ポリプロピレン製フィ ルムの余白部分を利用し, ガラスアンプル本体の限られ たラベルスペースでは記載が困難であった，安全投与に 関する情報やバーコードを記載したり，視認性を向上さ せるためのデザインを取り入れることが可能であること から，誤投薬や誤調剂の行われるリスクの軽減にも有効 である。

一方，医薬品の場合，あらかじめ薬価が決まってお り，供試品 $\mathrm{D} へ$ の包装形態変更に伴う新たなコストを 販売価格に転嫁することは難しく，製薬企業の負担増大 が危惧される．また，供試品 D は, プレフィルドシリ ンジ製剂より小型化は可能であるが, 従来のガラスアン プル製剂に比べ包装が大型化することで，麻薬や毒薬な ど保管スペースがあらかじめ限られている注射剂では， 実用化のうえで問題となる可能性がある.製薬企業にお けるコスト増減については，製品ごとに正式な金額を試 算することは，事実上困難であるが，供試品 $\mathrm{D}$ に変更 することで発生する販売包装形態および資材コストの変 更点は, 以下の通りと予測される . (1)ランニングコスト は，フィルムによる被覆包装を導入することにより，新 たな包装工程に二〜三千万円の追加設備投資が必要とな ることが予測され，生産能力(生産スピード)が少なくと も 20〜30\% 程度低下することが懸念される . (2)アンプ ルラベルは, 従来品が使用可能なためコスト変動はな い ．（3)外装フィルムは，包装資材費用が新たに発生する ためコストアップが予測されるが, 一般的に汎用されて いるポリプロピレン製フィルムを使用した場合，1本あ たりのコスト増はわずかであると推察される . (4)包装資 材全体については，外筒被覆包装化による緩衝性能向上 が期待されることで, ガラスアンプルを個装箱に入れる 際，ガラスアンプルが破損しないように一つ一つを区切 る波型の紙(ロンドレーション)を削除できる可能性が高 い. ロンドレーションが外筒被覆包装化で不要となれ ば, 相応のコストダウン効果があるものと推察される . さらに,このロンドレーション削除効果により，紙箱サ イズの大型化は低レベルに圧縮でき，相対的なコスト増 はわずかな見通しになるものと考えられる . 包装が大型 化しないと見込まれることで, 流通コストや貯蔵コスト に大きな影響を及ぼす可能性は低い，同時に，被覆包装 用フィルムが追加となるものの，ロンドレーション省略 により，医療機関で廃棄する包装資材の量も旧来品と変 わらないか, 逆に少なくなる可能性も期待できる .

以上より，供試品 D の導入に伴い，追加設備投資と 生産能力低下によるコスト増は懸念されるものの, 製品 自体の大幅なコスト増は見込まれないのではないかと考 えられる.また，今回われわれが開発した新包装形態は， 麻薬や抗がん斉など, 比較的薬価が高い薬剤への導入を
想定しており, 若干のコスト増は吸収できる可能性が期 待できる . 新たな包装工程に対する追加設備投資と生産 能力低下の問題を, 製薬企業がどのように判断するのか は不明である.しかし, 供試品 Dへの包装変更は, 既 存ガラスアンプル製剤を, プレフィルドシリンジ製剤や ポリアンプル製剤に変更するより，はるかに低コストで 製剂破損防止対策を講じることが可能となる．

そこで今後，供試品 Dをもとに，破損防止率の向上 と小型化, さらに容量の大きなガラスアンプルに対する 有用性を検証し，実用化に向けた具体的改良ならびに検 討を行う予定である。

謝辞 本試験を行うにあたり，供試品の作成ならびに提供 をしていただいた株式会社岩田レーベルの野田一彦氏, 自由 落下試験装置を供与していただいた第一三共株式会社の片山 通博氏に感謝いたします。

\section{引用文献}

1) A. Lurton, J. Ntiruhungwa, H. Saillant, J. Surugue, Stomach perforation by a blister-wrapped capsule, $N$. Engl. J. Med., 335, 754 (1996).

2) S.C. Dreskin, A prescription drug packaged in China and sold as an ethnic remedy, JAMA, 283, 2393 (2000).

3) B. Carriere, B. Bailey, G. Chabot, D. Lebel, Dispensing error leading to alendronate ingestion, Ann. Pharmacother., 37, 87-89 (2003).

4) A. Pathak, J.M. Senard, T. Bujaud, H. Bagheri, M. Lapeyre-Mestre, M.C. Tressieres, J.L. Montastruc, Me dication error caused by confusing drug blisters. Lancet, 363, 2142 (2004).

5) N. Langford, E. Graham-Clarke, Confusing tablets, Lancet, 366, 154 (2005).

6) E. Mein, F. Sii, P. Shah, An ocular medication dispens ing error, Br. J. Clin. Pharmacol., 62, 715-716 (2006).

7) 大脇奈保子, 間瀬定政, 柴田ゆうか, 牛田誠, 増田 修三, 柴田友紀子, 上町亜希子, 小川克己, 熊谷美 香子, 横田学, 早川達, 多施設共同による錠・カプ セル剂の開封性に関する検討, 医療薬学，30, 312320 (2004).

8) 田中邦佳, 三上ひとみ, 濱口常男, 門林宗男, ねじ 込み型点眼容器キャップの開けやすさに及ぼす開栓 トルク值の影響，医療薬学，31, 815-821 (2005).

9) 伊集院一成, 廣育彦, 谷古宇秀, 経口剂(錠剂)の大 きさに関する検討，医薬ジャーナル，42, 2154-2159 (2006).

10) 彦田絵美, 高橋瑞穂, 柳川忠二, 小名木敦雄, 柴田 家門, 定本清美, 散剂・顆粒剂分包包装の開封性評 価 - 障害患者に必要な条件の検討 - , 医療薬学, 33, 840-846 (2007).

11) 山本雅人, 鍋島俊隆, 病院薬斉師が製薬企業に望む 
こと - 国立大学法人附属病院におけるアンケート調 査 - , 臨床薬理 , 36, 305-313 (2005).

12) 西川憲清, 吳雅美, 川崎佳巳, 三ヶ尻健一, 西田直 子，田中康夫，製造番号シール紙添付による眼内注 入薬の安全管理, 臨床眼科, 61, 71-73 (2007).

13) 黑山政一, 平山武司, 生食 PFSの有用性に関する 検討 - アンケート調査と操作性試験 - , 薬理と治 療, 34, 489-497 (2006).
14) 平山武司, 黑山政生, 食注シリンジ「NP」の有用 性に関する研究 - 利便性および作業効率 - , 新薬と 臨床, 54, 1432-1443 (2005).

15)鈴木利保, 福山東雄, 中原有美, 西山純一, 金沢正 浩, 伊藤健二, 救急領域におけるドパミンプレフィ ルドシリンジの有用性の検討 - アンケート調査を中 心として - , 臨床麻酔 , 29, 1149-1156 (2005). 